\title{
Complete oxidation of 1,4-dioxane over zeolite-13X-supported Fe catalysts in the presence of air
}

\author{
C. Ramakrishna*, R. Krishna, T. Gopi, G. Swetha, Bijendra Saini, S. Chandra Shekar, \\ Anchal Srivastava \\ Evaluation Facility, Chemical Defence Equipments Evaluation Facility (CDEF), Defence R\&D Establishment, Jhansi Road, Gwalior-474002, India
}

\section{A R T I C L E I N F O}

\section{Article history:}

Received 30 September 2015

Accepted 9 December 2015

Published 5 February 2016

\section{Keywords:}

Iron

Zeolite-13X

1,4-Dioxane

Catalytic degradation

Complete oxidation

Degradation mechanism

\begin{abstract}
A B S T R A C T
Zeolite-13X-supported Fe (Fe/zeolite-13X) catalysts with various Fe contents were prepared by the wet impregnation method. The catalysts were characterized by $\mathrm{N}_{2}$ adsorption-desorption isotherms to estimate the Brunauer-Emmett-Teller surface areas and Barrett-Joyner-Hanlenda pore size distributions. X-ray diffraction, scanning electron microscopy, temperature-programmed reduction, and temperature-programmed desorption of $\mathrm{NH}_{3}$ were used to investigate the textural properties of the Fe/zeolite-13X catalysts. Their catalytic activities were determined for the complete oxidation of 1,4-dioxane using air as the oxidant in a fixed-bed flow reactor in the temperature range 100-400 ${ }^{\circ} \mathrm{C}$. The influences of various process parameters, such as reaction temperature, metal loading, and gas hourly space velocity (GHSV), on the dioxane removal efficiency by catalytic oxidation were investigated. The stability of the catalyst was tested at $400{ }^{\circ} \mathrm{C}$ by performing time-on-stream analysis for $50 \mathrm{~h}$. The Fe/zeolite-13X catalyst with $6 \mathrm{wt} \%$ Fe exhibited the best catalytic activity among the $\mathrm{Fe} /$ zeolite-13X catalysts at $400{ }^{\circ} \mathrm{C}$ and a GHSV of $24000 \mathrm{~h}^{-1}$, with $97 \%$ dioxane conversion and $95 \%$ selectivity for the formation of carbon oxides $\left(\mathrm{CO}\right.$ and $\left.\mathrm{CO}_{2}\right)$. Trace amounts $(<3 \%)$ of acetaldehyde, ethylene glycol monoformate, ethylene glycol diformate, 1,4-dioxane-2-ol, 1,4-dioxane-2one, and 2-methoxy-1,3-dioxalane were also formed as degradation products. A plausible degradation mechanism is proposed based on the products identified by GC-MS analysis.
\end{abstract}

(C) 2016, Dalian Institute of Chemical Physics, Chinese Academy of Sciences. Published by Elsevier B.V. All rights reserved.

\section{Introduction}

Catalytic removal of organic pollutants has attracted considerable interest owing to the high toxicity and low detection limits of these compounds. However, highly toxic pollutants that have adverse effects on the environment are regulated by stringent environmental policies [1,2]. However, some non-biodegradable substances are still a threat to ecosystems and human health. 1,4-Dioxane is an example of such a pollutant. 1,4-Dioxane is frequently used as an industrial solvent and as a solvent stabilizer [3] in many industrial processes, such as of the production of pulp, textiles, and electronics. In addition, it is an undesired byproduct in the production of surfactants and polyethylene terephthalate processes [4], and is widely used in consumer products like cosmetics and personal care products [5,6]. Its widespread use in many industrial processes and high solubility in water leads to contamination of surface groundwater [7]. According to the United States Environmental Protection Agency (US EPA) 2003 report, around 1146641 pounds of dioxane is released into the atmosphere every year,

\footnotetext{
* Corresponding author. Tel: +91-7103-280702/+918551894451; Tel/Fax: +91-7103-280610; E-mail: ramakrishna.drde@gmail.com This work was supported by the Director, DRDE (DRDO), Ministry of Defence, India. 
of which 105484 pounds is released into the atmosphere and the rest is released into surface water, land, and off-site. 1,4-Dioxane is suspected to damage the central nervous system and cause liver and kidney failure. Furthermore, it is a potential carcinogen to animals and also a probable carcinogen to human beings [8]. 1,4-Dioxane is classified as a Group 2B carcinogen by the International Agency for Research on Cancer and it falls under the regulations of the US EPA, which has set a limit of 30 $\mu \mathrm{g} / \mathrm{L}$ for drinking water at a $10^{-5}$ risk level. Therefore, dioxane is a hazardous waste and a priority pollutant for human health and ecosystems.

Conventional water treatment techniques have limited effectiveness for the treatment of dioxane-contaminated water because of its high solubility in water and low vapor pressure. Its high resistance to biotransformation $[9,10]$ also limits the effective application of biological processes. However, the use of enriched microbial cultures shows some level of dioxane biodegradation [11]. Furthermore, carbon adsorption and air stripping are not cost effective for the removal of dioxane from contaminated water. Therefore, development of new technologies for the treatment of dioxane in industrial wastewater and the atmosphere is required.

Advanced oxidation processes using ozone have been investigated for treating dioxane. Adams and co-workers [12] used the $\mathrm{O}_{3} / \mathrm{H}_{2} \mathrm{O}_{2}$ process to enhance the biodegradability of 1,4-dioxane. Kwon et al. [13] developed double and triple systems $\left(\mathrm{O}_{3}, \mathrm{O}_{3} /\right.$ ultraviolet ( $\left.\mathrm{UV}\right)$, and $\left.\mathrm{O}_{3} / \mathrm{UV} / \mathrm{H}_{2} \mathrm{O}_{2}\right)$ for effective treatment of dioxane-contaminated water. Beckett et al. [14] reported improved biodegradation of dioxane using ultrasound sonication. More recent studies have focused on photocatalysis using titania nanoparticles for the degradation of dioxane in aqueous media [15-19].

Industrial treatment before dioxane is released into water, land, and the atmosphere is the best way to prevent its hazardous effects. Thermal oxidation, catalytic oxidation, adsorption, and incineration are frequently used to treat volatile organic pollutants in many industrial processes. Among these methods, catalytic oxidation is a promising effluent treatment method to control the emission of toxic/hazardous substances. Many methods have been reported for catalytic oxidation using transition metals and metal oxide catalysts for gas-phase catalytic oxidation of hydrocarbons, methanol, acetone, and chlorobenzene with air as the oxidant [20-22]. Recently, supported metal oxide catalysts/nanocatalysts have gained considerable attention because of their better catalytic performance compared with the bulk metal oxide materials owing to their larger surface area, smaller particle size, and densely populated unsaturated surface coordination sites [23,24].

Industrial air emission treatment is the best choice for continuous elimination/reduction of the release of toxic/hazardous matter into the atmosphere. In the present study, we aimed to decompose 1,4-dioxane to carbon oxides using catalytic oxidation with air as the oxidant in a fixed-bed flow reactor to test the continuous removal efficiency. We chose zeolite-13X-supported iron oxide catalysts for dioxane treatment because of their low cost and ready availability. Furthermore, zeolite-13X materials are mesoporous with high specific surface area, and iron is a proven catalyst for many industrial processes, such as catalytic removal of ethyl benzene, cyclohexane, and hexadecane [25-31].

Battin et al. [32] also investigated gas-phase oxidation of equimolecular mixtures of 1,4-dioxane and $\mathrm{O}_{2}$ in a conventional static apparatus in the temperature range $200-400{ }^{\circ} \mathrm{C}$ at low pressure (10-300 Torr). They reported formation of $\mathrm{CO}, \mathrm{CO}_{2}$, $\mathrm{HCHO}, \mathrm{H}_{2}, \mathrm{C}_{2} \mathrm{H}_{4}$, and $\mathrm{H}_{2} \mathrm{O}$ as the main thermal oxidation products, small amounts of acetaldehyde and acrolein, and trace amounts of $\mathrm{CHO}-\mathrm{CHO}, \mathrm{CH}_{3} \mathrm{O}-\mathrm{CH}_{2}-\mathrm{CHO}$, and $\mathrm{CH}_{3}-\mathrm{CH}_{2} \mathrm{O}-\mathrm{CH}_{2}-\mathrm{CHO}$ as the gas-phase oxidation products. However, their process was not catalytic and also suffers from many disadvantages, such as poor selectivity and autoinhibition of the reaction at longer residence times.

In the present study, we investigated the influence of various process parameters on the catalytic removal of dioxane using air as an oxidant, such as reaction temperature, metal loading, and gas hourly space velocity (GHSV). We focused on the long-term stability and effectiveness of the catalytic process for complete oxidation of dioxane, and propose a probable degradation pathway for the products identified by gas chromatography-mass spectroscopy (GC-MS) analysis.

\section{Experimental}

\subsection{Materials}

$\mathrm{Fe}\left(\mathrm{NO}_{3}\right)_{3} \cdot 9 \mathrm{H}_{2} \mathrm{O}$ (purity 99\%) and 1,4-dioxane (purity 99\%) were purchased from Sigma-Aldrich India Pvt. Ltd. Zeolite 13X was purchased from Sorbead India Ltd. Nitrogen (purity 99.99\%) and air (purity 99.99\%, 22\% $\mathrm{O}_{2}$ by volume) gas cylinders were supplied by Baruka Gases India Ltd. Mass flow controllers (MFCs, precision $\pm 1 \%$ ) were procured from Sierra, Switzerland. CO (range 1-2000 ppm, \pm 1 ppm) and $\mathrm{CO}_{2}$ (range 10-20000 ppm, \pm 10 ppm) analyzers (Technovation Analytical Instruments Ltd. India) were used to measure the concentrations of carbon oxides. The temperature controller was purchased from West Control Solutions (West 6400, UK) and the infusion pump was purchased from KD Scientific 2000 India Ltd..

\subsection{Preparation of the catalyst}

Zeolite-13X-supported iron (Fe/13X) catalysts of different compositions were prepared by the wet impregnation method. Impregnation was achieved by soaking the crushed zeolite-13X (sieved to BSS 18/25 mesh) support in $60 \mathrm{~mL}$ of an aqueous solution containing the requisite amount of $\mathrm{Fe}\left(\mathrm{NO}_{3}\right)_{3} \cdot 9 \mathrm{H}_{2} \mathrm{O}$ for $3 \mathrm{~h}$ and subsequent water evaporation in a microwave oven. The catalyst material was then dried in a vacuum oven at 120 ${ }^{\circ} \mathrm{C}$ for $10 \mathrm{~h}$. The resulting catalyst was activated by calcination in air for $4 \mathrm{~h}$ at $400{ }^{\circ} \mathrm{C}$. Fe/13X catalysts with $2,4,6$, and $8 \mathrm{wt} \%$ Fe were prepared and activated.

\subsection{Physicochemical characterization of the catalysts}

$\mathrm{N}_{2}$ adsorption-desorption isotherms of $\mathrm{Fe} / 13 \mathrm{X}$ calcined cat- 
alysts were obtained using a Micromeritics ASAP-2010 unit at liquid nitrogen temperature $\left(-196^{\circ} \mathrm{C}\right)$. Prior to the analysis, all of the catalysts were degassed for $60 \mathrm{~min}$ at $120{ }^{\circ} \mathrm{C}$. Brunauer-Emmett-Teller (BET) and Barrett-Joyner-Halenda (BJH) methods were used to estimate the specific surface areas and pore size distributions of the catalysts, respectively. X-ray diffraction (XRD) patterns of all of the catalysts were recorded on a Rigaku Miniflex diffractometer (Rigaku Corporation, Japan) using a Ni-filtered $\mathrm{Cu} K_{\alpha}$ radiation $(\lambda=1.5406 \AA)$ source. The scans were performed over the $2 \theta$ range $10^{\circ}-80^{\circ}$ with a scan speed of $2 \% \mathrm{~min}$ at $30 \mathrm{kV}$ and $50 \mathrm{~mA}$. Temperature-programmed reduction (TPR) and temperature-programmed desorption (TPD) experiments were performed on a TPR/TPD Nuchrom Unit with a thermal conductivity detector. TPR studies were performed by loading $100 \mathrm{mg}$ of the catalyst sample in a quartz reactor with $5 \% \mathrm{H}_{2}-\mathrm{Ar}$ mixture $(50 \mathrm{~mL} / \mathrm{min})$ in the temperature range $40-750{ }^{\circ} \mathrm{C}$ with $10{ }^{\circ} \mathrm{C} / \mathrm{min}$ heating rate. For the $\mathrm{NH}_{3}$-TPD experiments, the catalyst samples were preheated for $1 \mathrm{~h}$ at $300{ }^{\circ} \mathrm{C}$ and then $\mathrm{NH}_{3}$ gas was dosed by pulsing onto the catalyst at $100{ }^{\circ} \mathrm{C}$ until saturation. The samples were then allowed to cool at $40^{\circ} \mathrm{C}$ until base line stabilization. After base line restoration, the samples were heated from $40-750{ }^{\circ} \mathrm{C}$ with a heating rate of $10{ }^{\circ} \mathrm{C} / \mathrm{min}$ in $\mathrm{He}(50 \mathrm{~mL} / \mathrm{min})$. The surface morphologies of the catalysts were determined by scanning electron microscopy (SEM, JOEL, JAX-840) at $20 \mathrm{kV}$ by gold sputtering on the samples.

\subsection{Activity studies}

Gas-phase catalytic oxidation of 1,4-dioxane was carried out at atmospheric pressure using a fixed-bed continuous flow reactor (20 $\mathrm{mm}$ inner diameter, $120 \mathrm{~mm}$ length) interfaced with an online gas chromatograph with flame-ionization and photoionization detectors (GC/FID/PID, Nucon Engineers Pri- vate Ltd., India). A schematic representation of the experimental setup is shown in Fig. 1.

1,4-Dioxane, nitrogen, and air were used in this study. The gas flow rates were maintained by MFCs. A precise infusion pump was used to control the dioxane flow rate $(0.01 \mathrm{~mL} / \mathrm{min})$ into the preheating chamber. For the reaction studies, Fe/13X catalyst ( $2.5 \mathrm{~g}$ ) diluted with glass beads was packed into a glass reactor with glass wool and mounted vertically in an electrically heated tubular furnace with profile controller. Another thermocouple was placed inside the reactor in contact with the catalyst bed to measure the temperature of the catalyst bed. Prior to the experiment, the catalyst was calcined at $400{ }^{\circ} \mathrm{C}$ in air for $1 \mathrm{~h}$. Nitrogen-saturated dioxane (1300 ppm) vapor was passed through the reactor. The reaction was studied in the temperature range $100-400{ }^{\circ} \mathrm{C}$ with GHSVs from 24000 to $54000 \mathrm{~h}^{-1}$. Analysis of the gaseous mixture exiting the catalyst bed was carried out using a GC/FID/PID equipped with a BP-10 capillary column $(30 \mathrm{~m} \times 0.25 \mathrm{~mm})$ for partial oxidation products (POPs) and reactants. The $\mathrm{CO}$ and $\mathrm{CO}_{2}$ concentrations were analyzed using calibrated CO (SR 94 electrochemical based detectors) and $\mathrm{CO}_{2}$ (IR based detectors, P90, Technovation Analytical Instruments Ltd., India) analyzers, respectively. The product mixture of the condensable phase was trapped in acetonitrile solvent at $-5{ }^{\circ} \mathrm{C}$ and analyzed by a GC equipped with a FID detector. Qualitative analysis was carried out by a GC-MS (Agilent 6890N) equipped with mass-selective detector using a HP-5 (30 m × $0.25 \mathrm{~mm})$ column.

\subsection{Analytical procedure for catalytic oxidation of dioxane}

Catalytic oxidation of dioxane by air produces $\mathrm{CO}$ and $\mathrm{CO}_{2}$ as the major products (complete oxidation products of dioxane) and trace amounts $(<3 \%)$ of acetaldehyde, ethylene glycol monoformate (EGMF), ethylene glycol diformate (EGDF),

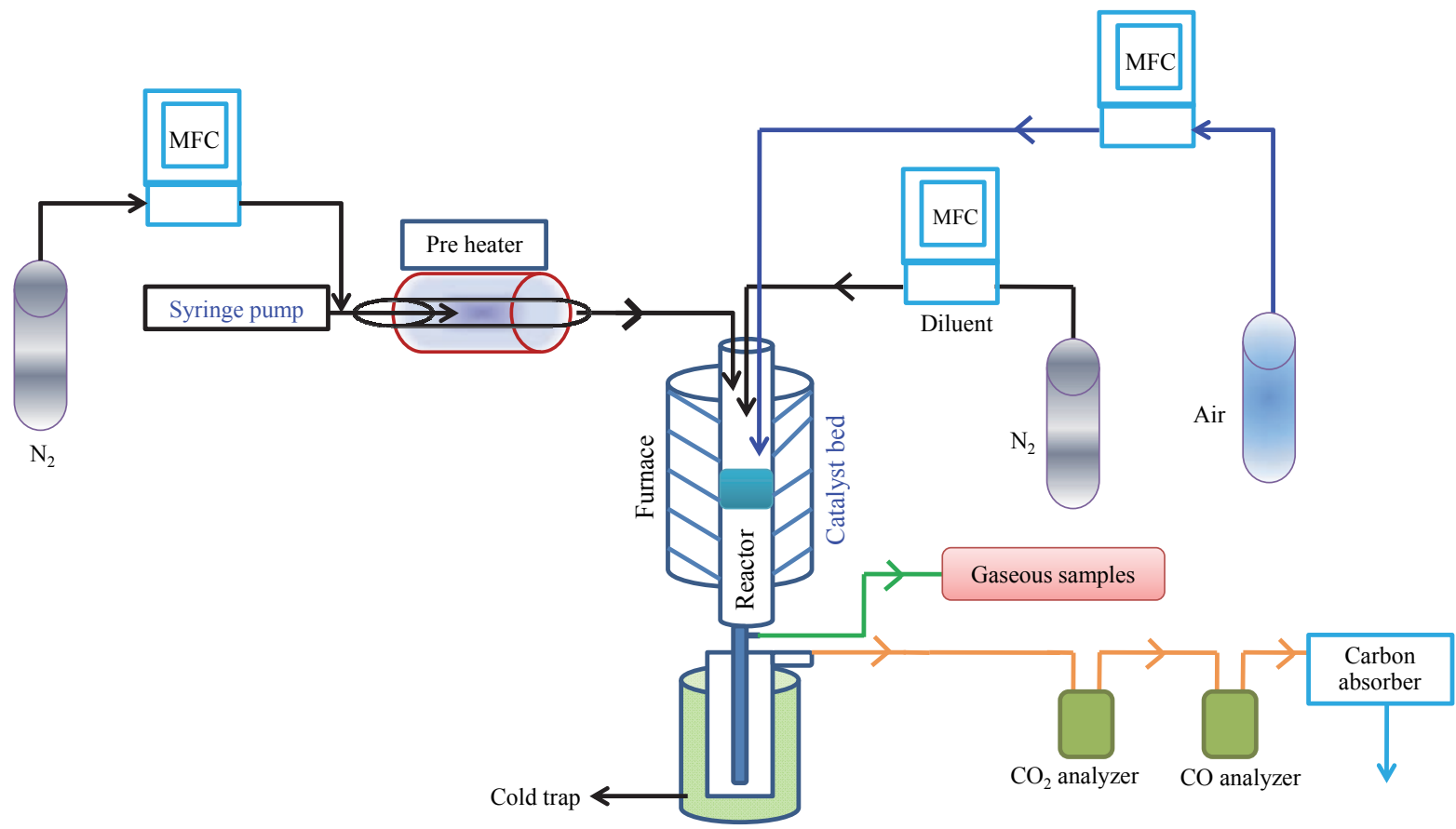

Fig. 1. Schematic diagram of the typical experimental set-up used for the complete oxidation of dioxane over Fe/13X catalysts. 
1,4-dioxane-2-ol, 1,4-dioxane-2-one, 2-methoxy-1,3-dioxalane as POPs. Conversion is defined as the number of moles of product formed per mole of reactant per gram of catalyst. The catalytic activity results are expressed in term of dioxane conversion, and the calculation is based on the disappearance of dioxane from the flow. The outlet and inlet concentrations of dioxane are determined using the online GC/FID area. The percentage conversion of dioxane, selective oxidation to $\mathrm{CO}_{x}$ ( $\mathrm{CO}_{x}$ selectivity) and POPs (POPs selectivity), and percentage $\mathrm{CO}_{x}$ yield $\left(\mathrm{CO}_{x}\right.$ yield $)$ are calculated as follows:

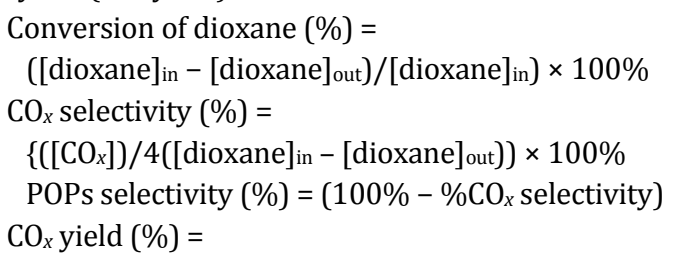

(\%conversion of dioxane $\times \% \mathrm{CO}_{x}$ selectivity) $/ 100 \%$

The selectivity of each POP is the ratio of the molar concentration of the POP to the total concentration of all products formed. The yield of each POP is calculated from the molar selectivity of the POP and the molar conversion of dioxane. The combined selectivity for $\mathrm{CO}$ and $\mathrm{CO}_{2}$ is $100 \%-\%$ POPs selectivity.

\section{Results and discussion}

\subsection{Characterization of $\mathrm{Fe} / 13 \mathrm{X}$ systems}

\subsubsection{Effect of Fe content on specific surface area}

The BET surface area, Langmuir surface area, pore volume, and average pore diameter were calculated from $\mathrm{N}_{2}$ adsorption-desorption isotherms measurements, and the results are shown in Table 1.

The total surface area was calculated according to the BET and Langmuir methods [34]. All of the catalysts (2, 4, 6, and 8 $w t \% \mathrm{Fe} / 13 \mathrm{X}$ ) exhibited type IV adsorption isotherms typical of mesoporous materials with H3 type hysteresis. The isotherms also indicated the presence of slit-type pores formed because of aggregation of iron oxide species. The surface areas of the $\mathrm{Fe} / 13 \mathrm{X}$ catalysts are in the range 166 to $633 \mathrm{~m}^{2} / \mathrm{g}$, and decrease with increasing Fe content. The decrease in the surface area is more pronounced between 6 and $8 \mathrm{wt} \% \mathrm{Fe}$. The pore size distributions of all of the Fe/13X catalysts are shown in Fig. 2. From the data, the pore size distributions have a narrow range and most of the pores are in mesoporous range (20-40 $\AA$ ), which is ascribed to the zeolite-13X support. However, the mesoporous volume is higher at lower Fe loadings and it tends

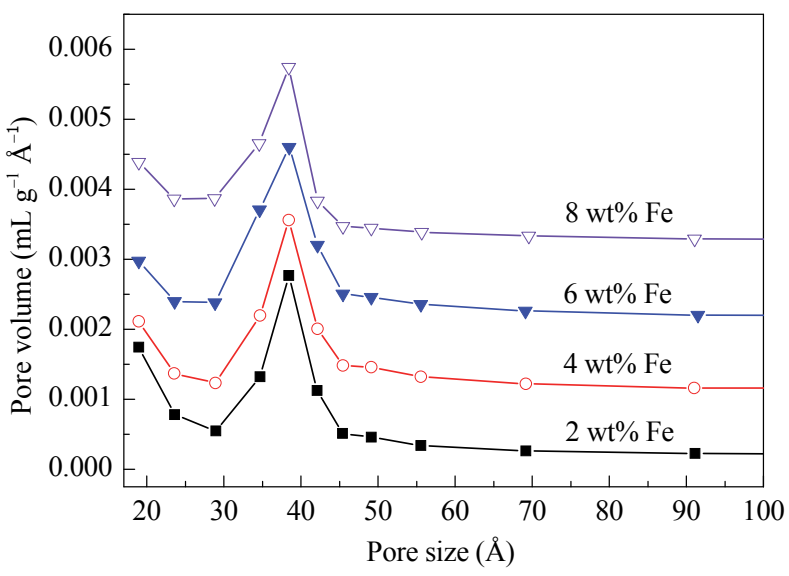

Fig. 2. Pore size distributions of $\mathrm{Fe} / 13 \mathrm{X}$ catalysts with different $\mathrm{Fe}$ loadings.

to decrease with increasing metal loading, as shown in Table 1. This can be attributed to iron oxide particles filling the macropores of zeolite 13X, and thus the number of mesopore is higher at lower metal content. The mesoporous volume is lower at higher Fe loading because of the formation of larger iron oxide species. As a result, there is a considerable decrease in the pore volume and surface area as well as an increase in pore size. From the $\mathrm{N}_{2}$ adsorption-desorption studies, we conclude that the decreases of the surface area and pore volume of the catalysts with increasing Fe loading are because of impregnation of low surface area iron oxide in the porous zeolite-13X support [35].

\subsubsection{Effect of Fe content on the aggregation state of Fe}

XRD patterns of zeolite $13 \mathrm{X}$ along with the $2,4,6$, and $8 \mathrm{wt} \%$ $\mathrm{Fe} / 13 \mathrm{X}$ calcined catalysts are shown in Fig. 3. The diffraction signals at $2 \theta=15.4^{\circ}, 20.1^{\circ}, 23.3^{\circ}, 26.7^{\circ}$, and $31^{\circ}$ corresponding to the (331), (440), (533), (642), and (662) planes and their $d$ values of $5.742,4.424,3.817,3.345$, and 2.871, respectively, are only those of zeolite 13X [33]. No separate diffraction signals are observed for the iron oxide $\left(\mathrm{Fe}_{x} \mathrm{O}_{y}\right)$ species, which indicates the high dispersion of $\mathrm{Fe}$ on the zeolite-13X support or the formation of an $\mathrm{Fe}_{x} \mathrm{O}_{y}$-zeolite-13X solid solution. However, the presence of iron oxide crystallites less than $5 \mathrm{~nm}$ in size cannot be ruled out, because this is below the detection limits of the powder XRD technique. The decrease in the intensity of all of the signals with increasing metal loading is attributed to iron absorption into the framework of the zeolite-13X support.

SEM images of 2, 4, 6, and $8 \mathrm{wt} \% \mathrm{Fe} / 13 \mathrm{X}$ calcined catalysts are shown in Fig. 4 . The images were taken at 5000 to $25000 \times$

Table 1

Physicochemical properties of the $\mathrm{Fe} / 13 \mathrm{X}$ catalysts.

\begin{tabular}{|c|c|c|c|c|c|c|c|c|c|}
\hline \multirow{2}{*}{ Catalyst } & \multirow{2}{*}{$\begin{array}{l}\text { Fe content } \\
\text { (wt } \%)\end{array}$} & \multirow{2}{*}{$\begin{array}{l}\text { BET surface } \\
\text { area }\left(\mathrm{m}^{2} / \mathrm{g}\right)\end{array}$} & \multirow{2}{*}{$\begin{array}{l}\text { Langmuir surface } \\
\text { area }\left(\mathrm{m}^{2} / \mathrm{g}\right)\end{array}$} & \multirow{2}{*}{$\begin{array}{c}\text { Pore diameter } \\
(\AA)\end{array}$} & \multirow{2}{*}{$\begin{array}{l}\text { Pore volume } \\
\left(\mathrm{cm}^{3} / \mathrm{g}\right)\end{array}$} & \multicolumn{2}{|c|}{$\operatorname{TPR}\left({ }^{\circ} \mathrm{C}\right)$} & \multirow{2}{*}{$\begin{array}{c}\mathrm{H}_{2} \text { uptake } \\
(\mathrm{mL} / \mathrm{g})\end{array}$} & \multirow{2}{*}{$\begin{array}{c}\mathrm{NH}_{3}-\mathrm{TPD} \text { total } \\
\text { Acidity }(\mathrm{mmol} / \mathrm{g})\end{array}$} \\
\hline & & & & & & $T_{1 \max }$ & $T_{2 \max }$ & & \\
\hline Zeolite-13X & 0 & 746 & 762 & 23 & 0.437 & - & - & - & 4.78 \\
\hline $2 \mathrm{wt} \% \mathrm{Fe} / 13 \mathrm{X}$ & 2 & 633 & 655 & 25 & 0.396 & 506 & 626 & 2.85 & 10.53 \\
\hline $4 \mathrm{wt} \% \mathrm{Fe} / 13 \mathrm{X}$ & 4 & 450 & 466 & 26 & 0.299 & 543 & 650 & 6.34 & 13.39 \\
\hline $6 \mathrm{wt} \% \mathrm{Fe} / 13 \mathrm{X}$ & 6 & 350 & 365 & 28 & 0.250 & 553 & 653 & 9.16 & 15.31 \\
\hline $8 \mathrm{wt} \% \mathrm{Fe} / 13 \mathrm{X}$ & 8 & 166 & 173 & 39 & 0.165 & 564 & 656 & 7.28 & 12.94 \\
\hline
\end{tabular}




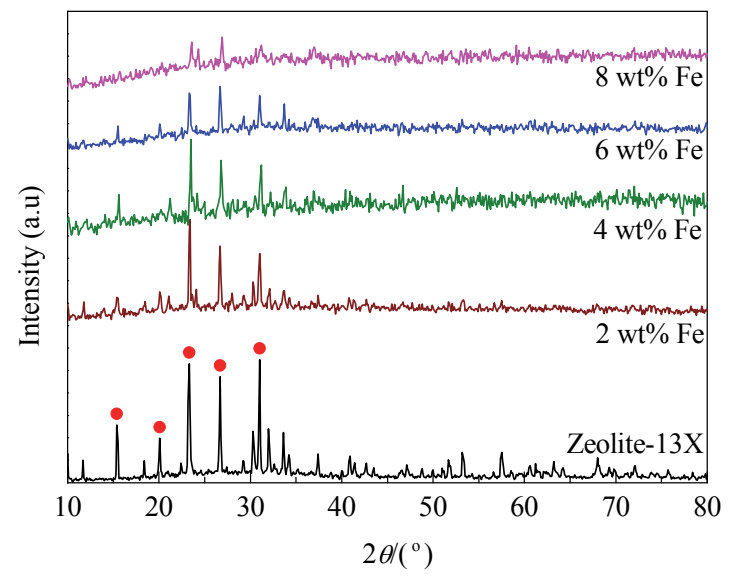

Fig. 3. XRD patterns of $\mathrm{Fe} / 13 \mathrm{X}$ catalysts with different Fe loadings calcined at $400{ }^{\circ} \mathrm{C}$.

magnification. From the SEM images, the iron distribution is uniform at lower loadings, that is, for 2 and 4 wt $\%$ iron loading, the distribution is uniform on the zeolite-13X support. Above 6 $\mathrm{wt} \%$ loading, the iron distribution is not uniform and the pore morphology is also slightly rough. Furthermore, for the $8 \mathrm{wt} \%$ iron catalyst, particle aggregate to form compact irregular shapes and clusters on the surface of the zeolite-13X support. The SEM images are in agreement with the textural and physicochemical properties.

\subsubsection{Nature of $\mathrm{Fe}_{x} \mathrm{O}_{y}$}

TPR experiments were performed on the calcined catalysts to determine the oxidation states of iron deposited on the zeolite-13X support and to relate these oxidation states to the activity of the catalysts. $\mathrm{H}_{2}$-TPR profiles of $2,4,6$, and $8 \mathrm{wt} \% \mathrm{Fe}$ loaded on zeolite-13X supports are shown in Fig. 5. The reducibility of iron oxide catalysts depends on the morphological properties of the support material, because the support material determines the reactivity of the bridging Fe-O-support functionalities [36]. As well as the morphological properties of the support, impurity levels, preparation procedures, and the reduction conditions, such $\mathrm{H}_{2}$ partial pressure and heating rate, also determine the reducibility of iron oxide catalysts. Therefore, the reduction temperatures obtained may be different

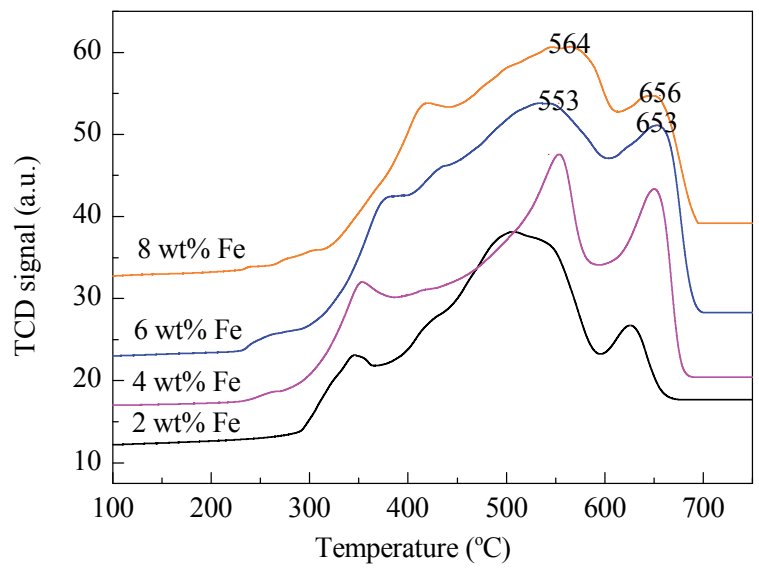

Fig. 5. $\mathrm{H}_{2}$-TPR profiles of the Fe/13X catalysts with different Fe loadings.

from other reported values [37]. All of the iron oxide catalysts show multistep reduction patterns (Fig. 5) in the temperature range $300-750{ }^{\circ} \mathrm{C}$, which indicates that the reduction of the iron oxide phase of these catalysts is similar to that of bulk iron oxide particles with weak interactions with the zeolite support.

The broad peak ( $T_{1 \max }$ ) between 300 and $600{ }^{\circ} \mathrm{C}$ (corresponding to consumption of hydrogen) is attributed to the reduction of $\mathrm{Fe}_{2} \mathrm{O}_{3}$ to $\mathrm{Fe}_{3} \mathrm{O}_{4}$. The broadening of the peak indicates that iron on the zeolite-13X support is present as highly dispersed clusters or isolated iron ions that can strongly interact with the support. In addition to broadening, a shoulder peak is present on the low temperature side of the first peak. This can be attributed to reduction of hydroxylated iron oxide species [38,39]. The high temperature peak $\left(T_{2 \max }\right)$ between 570 and $710{ }^{\circ} \mathrm{C}$ corresponds to the subsequent reduction of $\mathrm{Fe}_{3} \mathrm{O}_{4}$ to metallic Fe. With increasing Fe loading, the reduction peak area increases, indicating an increase of the active phase. The $T_{1 \max }$ and $T_{2 \max }$ values of these peaks shift to higher temperature with increasing Fe loading from 2 to 8 wt $\%$ (506 to $564{ }^{\circ} \mathrm{C}$ and 626 to $656{ }^{\circ} \mathrm{C}$, respectively) and the intensity of the peak also proportionally increases with increasing Fe loading up to 6 $w t \%$. The intensity of the peak slightly decreases from 6 to 8 wt\% loading (decrease in hydrogen uptake, as shown in Table 1). This is attributed to the formation of large iron oxide spe-
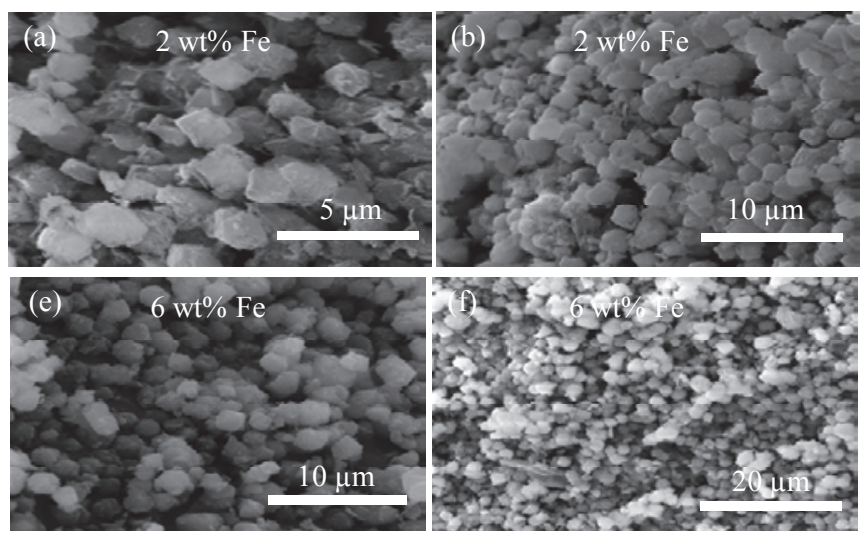
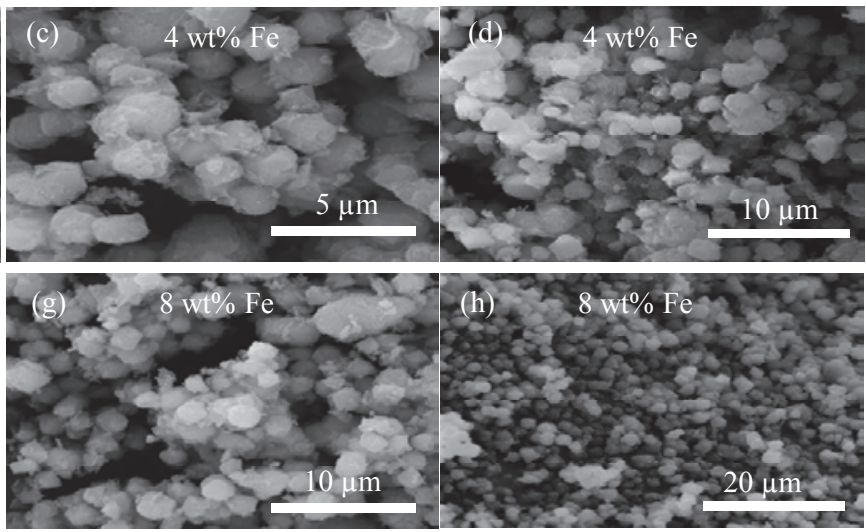

Fig. 4. SEM images of $2(a, b), 4(c, d), 6(e, f)$, and 8 (g, h) wt $\%$ Fe/13X catalysts at different magnifications. 
cies, which is verified by SEM, surface area, and pore size distribution analysis. The shifts of $T_{1 \max }$ and $T_{2 \max }$ are because of the weak interactions between iron oxide particles and the zeolite-13X support, absorption of iron oxide particles into the framework of the zeolite support, and the wide range of particle sizes of the iron oxide species. From the $\mathrm{H}_{2}$-TPR studies, we determined the presence of $\mathrm{Fe}_{2} \mathrm{O}_{3}$ and hydroxylated iron oxide species, and also their interactions with the zeolite-13X support.

\subsubsection{Acidic properties of the Fe/13X catalysts}

The performance of the catalyst depends on the quantity and strength of acidic sites on its surface. To determine the strengths of the acidic sites of the catalysts, $\mathrm{NH}_{3}$-TPD experiments were performed for the zeolite-13X support and all of the $\mathrm{Fe} / 13 \mathrm{X}$ catalysts in the temperature range $40-750{ }^{\circ} \mathrm{C}$, and the results are shown in Fig. 6 . The total acidities of the support and the catalysts are given in Table 1 . For the zeolite-13X support, there is only one broad peak in the $\mathrm{NH}_{3}$-TPD pattern in the region $250-730^{\circ} \mathrm{C}$, whereas two broad peaks are present in the all $\mathrm{Fe} / 13 \mathrm{X}$ catalysts: one peak in the temperature range $180-450{ }^{\circ} \mathrm{C}$ and the other at $450-730{ }^{\circ} \mathrm{C}$. The former represents $\mathrm{NH}_{3}$ desorption from strong acid sites. It appears that these acidic sites are responsible for the activity of the catalyst in the temperature range $250-400{ }^{\circ} \mathrm{C}$ [40]. However, the zeolite-13X support contains very few relatively strong acid sites, which could contribute to the catalytic activity in this temperature range. The broad peak in the high temperature range $450-730{ }^{\circ} \mathrm{C}$ represents $\mathrm{NH}_{3}$ desorption from very strong acid sites on the surface of the catalysts. However, these acidic sites may not contribute to the catalytic activity under the reaction temperatures investigated. The results shown in Table 1 reveal that with increasing metal loading, the total acidity increased for 2-6 wt $\% \mathrm{Fe} / 13 \mathrm{X}$ catalysts. In contrast, the total acidity for the $8 \mathrm{wt} \% \mathrm{Fe} / 13 \mathrm{X}$ catalyst decreased.

The lower total acidity for the $8 \mathrm{wt} \% \mathrm{Fe} / 13 \mathrm{X}$ catalyst is attributed to aggregation of iron oxide species in the framework of the zeolite-13X support because of sintering at high metal loading. From the $\mathrm{NH}_{3}$-TPD studies, it is concluded that iron oxide catalysts contain a wide range of strong acid sites, which

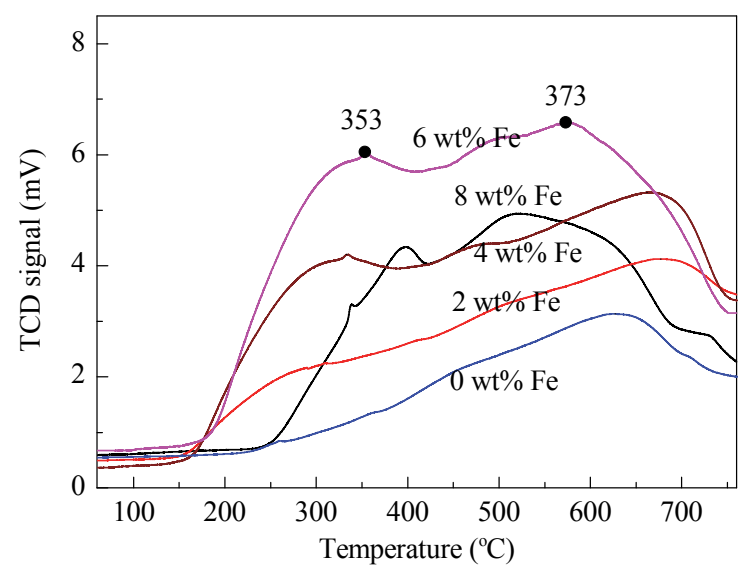

Fig. 6. $\mathrm{NH}_{3}$-TPD profiles of the Fe/13X catalysts with different Fe loadings. are responsible for the high activity of the Fe/zeolite-13X catalysts [41,42] under the operating reaction conditions. The $\mathrm{NH}_{3}$-TPD results are in good agreement with the activity studies of the iron oxide catalysts. Furthermore, they supports the better performance of the $6 \mathrm{wt} \% \mathrm{Fe} / 13 \mathrm{X}$ catalyst than the other $\mathrm{Fe} / 13 \mathrm{X}$ catalysts for the complete oxidation of dioxane because of the enhanced redox ability.

\subsection{Catalytic properties of Fe/13X systems}

\subsubsection{Effect of reaction temperature and metal loading on conversion of dioxane in air}

The effect of the reaction temperature on the catalytic oxidation of dioxane by air was investigated in the temperature range $100-400{ }^{\circ} \mathrm{C}$, and the results are shown in Fig. 7. The data indicates that dioxane is thermally stable and no product formation occurs when heating dioxane to $400{ }^{\circ} \mathrm{C}$ in the absence of the catalyst. In the presence of only the zeolite- $13 \mathrm{X}$ support, the catalytic activity is minimal up to $250{ }^{\circ} \mathrm{C}$. From $250-300{ }^{\circ} \mathrm{C}$, zeolite-13X exhibits slight activity for dioxane conversion. Above $300{ }^{\circ} \mathrm{C}$, the catalytic activity increases with reaction temperature and reaches about $37 \%$ conversion at $400{ }^{\circ} \mathrm{C}$. With the $\mathrm{Fe} / 13 \mathrm{X}$ catalysts, dioxane conversion slowly increases up to $250{ }^{\circ} \mathrm{C}$. With further increasing reaction temperature, dioxane conversion sharply increases and maximum conversion is achieved at $400{ }^{\circ} \mathrm{C}$. This tendency is expected because turnover frequencies increase with increasing reaction temperature. The influence of metal loading on dioxane conversion is also shown in Fig. 7. With increasing metal loading from 2 to $6 \mathrm{wt} \%$, the percentage conversion of dioxane increases in the temperature range $200-400{ }^{\circ} \mathrm{C}$, and almost $97 \%$ dioxane conversion is achieved with $6 \% \mathrm{Fe}$ catalyst at $400{ }^{\circ} \mathrm{C}$. This is attributed to the increase of active metal oxide species and the high surface area of the zeolite-13X support. In contrast, the dioxane conversion values with the $8 \mathrm{wt} \%$ iron oxide catalyst are lower than those of the $6 \mathrm{wt} \%$ Fe catalyst at all temperatures. It appears that above 6\% Fe loading, agglomeration of the catalyst occurs and large iron oxide species form, thereby decreasing the surface area and catalytic activity. The activity

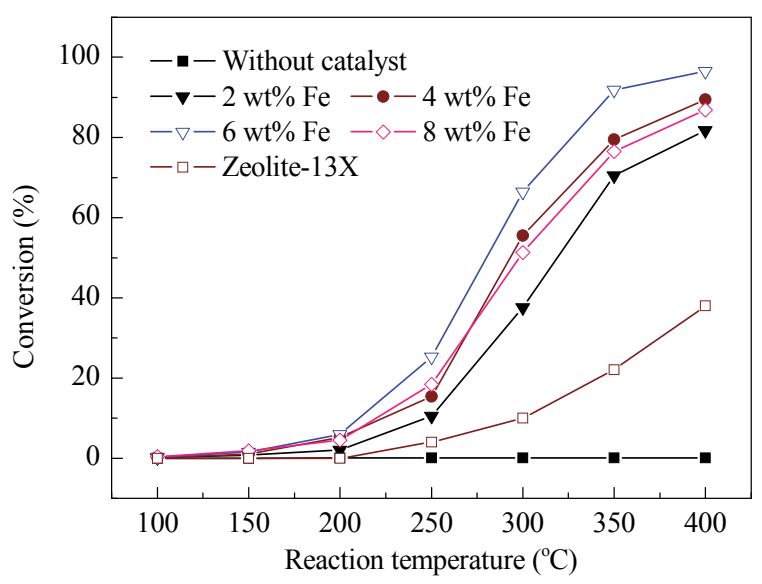

Fig. 7. Effect of reaction temperature and metal loading on steady-state oxidation of dioxane at GHSV of $24000 \mathrm{~h}^{-1}$ and $\mathrm{O}_{2}$ :dioxane molar ratio of 8. 
results agree well with the characterization data for all of the $\mathrm{Fe} / 13 \mathrm{X}$ catalysts, as discussed in Section 3.1. The reduced performance of the $8 \mathrm{wt} \% \mathrm{Fe} / 13 \mathrm{X}$ catalyst is also in agreement with the textural and physicochemical characterization data, which shows considerable decrease in the surface area because of aggregation of iron oxide species at high Fe loading. From the structure activity results, it is concluded that $6 \mathrm{wt} \% \mathrm{Fe}$ is optimum for conversion of dioxane, and this loading was used for further experiments.

\subsubsection{Selective oxidation to carbon oxides}

Because the aim of this study is to completely oxidize 1,4-dioxane and prevent the formation of POPs, the activity of the catalysts is described in terms of the selective formation of $\mathrm{CO}$ and $\mathrm{CO}_{2}$. However, in the present study, the concentrations of all of the POPs (i.e., acetaldehyde, EGMF, EGDF, 1,4-dioxane-2-ol, 1,4-dioxane-2-one, 2-methoxy-1,3-dioxalane) are $<3 \%$ according to the GC area. The effect of reaction temperature on dioxane conversion and its product distribution over the 6 wt\% Fe/13X catalyst is shown in Fig. 8. The results reveal that with increasing reaction temperature from 200-350 ${ }^{\circ} \mathrm{C}$, the selectivity for the formation of $\mathrm{CO}_{2}$ gradually increases from $28 \%$ to $70 \%$ and $\mathrm{CO}$ selectivity also increases from $8 \%$ to $12 \%$. Above $350{ }^{\circ} \mathrm{C}$, selectivity for $\mathrm{CO}_{2}$ formation sharply increases and reaches $\sim 82 \%$ at $400{ }^{\circ} \mathrm{C}$, whereas the selectivity for CO formation slightly decreases to $10 \%$ at the same temperature. Similarly, the molar yields of both $\mathrm{CO}$ and $\mathrm{CO}_{2}$ rapidly increase up to $350{ }^{\circ} \mathrm{C}$ and reach $68 \%$ and $12 \%$, respectively. The corresponding molar yields of $\mathrm{CO}_{2}$ and $\mathrm{CO}$ at $400{ }^{\circ} \mathrm{C}$ are $80 \%$ and $8 \%$, as shown in the Fig. 8 . This tendency is attributed to the complete oxidation of the POPs formed on the surface of the $\mathrm{Fe} / 13 \mathrm{X}$ catalysts above $350{ }^{\circ} \mathrm{C}$. Therefore, at higher temperatures, $\mathrm{CO}_{2}$ formation is predominant over $\mathrm{CO}$ formation, although both $\mathrm{CO}$ and $\mathrm{CO}_{2}$ formed at all of reaction temperatures studied.

\subsubsection{Effect of GHSV on dioxane conversion and $\mathrm{CO}_{x}$ selectivity}

The effect of the GHSV on dioxane conversion and the yields of the complete oxidation products over the 6 wt\% Fe/13X

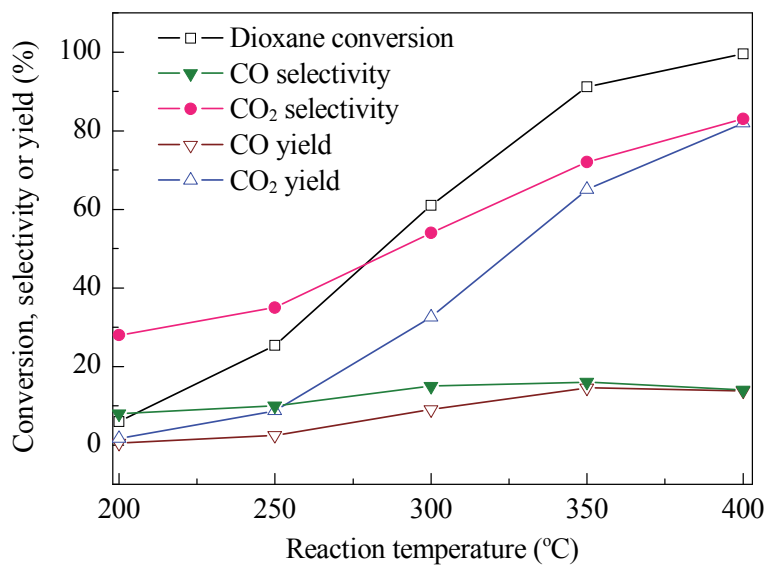

Fig. 8. Effect of reaction temperature on steady-state oxidation of dioxane and product selectivity over the $6 \mathrm{wt} \% \mathrm{Fe} / 13 \mathrm{X}$ catalyst at GHSV of $24000 \mathrm{~h}^{-1}$ and $\mathrm{O}_{2}$ :dioxane molar ratio of 8. catalyst was investigated at different reaction temperatures, and the results are shown in Fig. 9. With increasing GHSV from 24000 to $54000 \mathrm{~h}^{-1}$, the percentage conversion of dioxane gradually decreases from $97 \%$ to $82 \%$ at $400{ }^{\circ} \mathrm{C}$. At 350 and $300{ }^{\circ} \mathrm{C}$, dioxane conversion decreases from $89 \%$ to $75 \%$ and $60 \%$ to $36 \%$ with increasing GHSV from 24000 to $54000 \mathrm{~h}^{-1}$, respectively. This tendency is attributed to the decrease of the contact time between the reactant and the catalyst with increasing GHSV. The yields of the complete oxidation products also proportionally decrease with the conversion values at 400 and $350{ }^{\circ} \mathrm{C}$. In contrast, the yields of the complete oxidation products at $300{ }^{\circ} \mathrm{C}$ sharply decrease from $57 \%$ to $15 \%$. It is interesting that the influence of GHSV is more significant at lower reaction temperature $\left(300{ }^{\circ} \mathrm{C}\right)$ than at higher reaction temperatures $\left(350\right.$ and $\left.400{ }^{\circ} \mathrm{C}\right)$. It appears that at higher reaction temperatures $\left(350\right.$ and $\left.400{ }^{\circ} \mathrm{C}\right)$, the POPs initially formed in the catalytic reaction are involved in further oxidation to produce the complete oxidation products, that is, thermal effects are more pronounced at higher reaction temperatures. At lower reaction temperature $\left(300{ }^{\circ} \mathrm{C}\right)$, the surface oxidation potential of the catalyst may not be sufficient to convert the POPs to the complete oxidation products, that is, thermal effects are less significant at lower reaction temperatures.

\subsubsection{Time-on-stream analysis}

Time-on-stream analysis of dioxane oxidation over the 6 wt $\% \mathrm{Fe} / 13 \mathrm{X}$ catalyst was carried out at $400{ }^{\circ} \mathrm{C}$ for $50 \mathrm{~h}$, and the yields of the oxidation products as a function of time are shown in Fig. 10. Here, it is noteworthy that the catalyst exhibits constant activity for complete oxidation of dioxane (97\% conversion) to $\mathrm{CO}$ and $\mathrm{CO}_{2}$ for $5 \mathrm{~h}$ and the yields of carbon oxides are about $92 \%$. However, the percentage conversion of dioxane gradually decreases to $80 \%$ after $50 \mathrm{~h}$ continuous operation at $400{ }^{\circ} \mathrm{C}$. The yields of $\mathrm{CO}_{x}$ proportionally decrease to $65 \%$. The decrease in the percentage conversion and $\mathrm{CO}_{x}$ yields is attributed to the formation of coke on the catalyst surface at higher reaction temperatures, thereby blocking of some of the active sites that are responsible for the catalytic activity. From these results, it is concluded that the iron oxide catalyst sup-

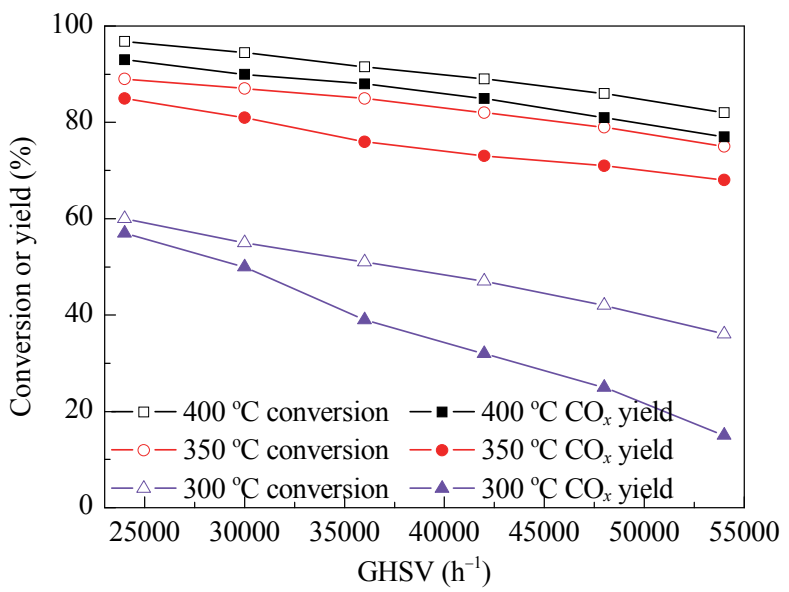

Fig. 9. Effect of GHSV on steady-state oxidation of dioxane and yield of complete oxidation products over the $6 \mathrm{wt} \% \mathrm{Fe} / 13 \mathrm{X}$ catalyst at various temperatures and an $\mathrm{O}_{2}$ :dioxane molar ratio of 8 . 


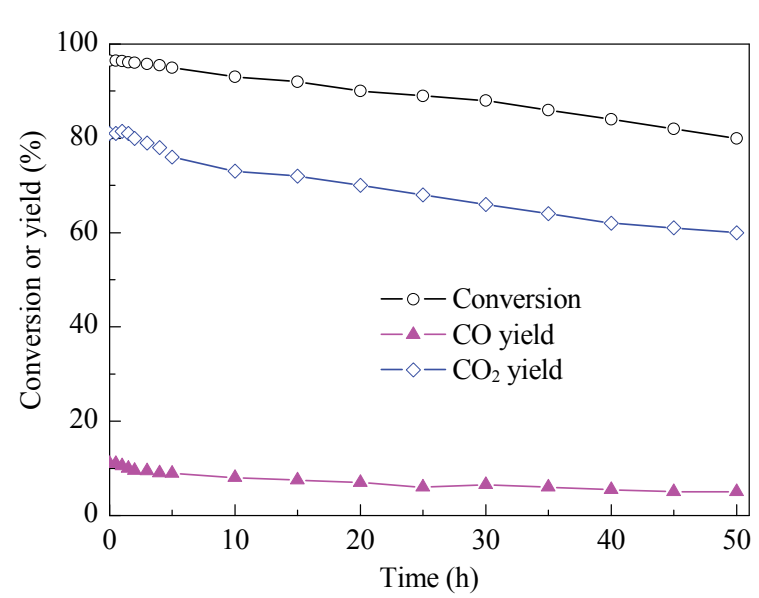

Fig. 10. Time-on-stream analysis over the $6 \mathrm{wt} \% \mathrm{Fe} / 13 \mathrm{X}$ catalyst at $400{ }^{\circ} \mathrm{C}$ with GHSV of $24000 \mathrm{~h}^{-1}$, dioxane concentration of $1300 \mathrm{ppm}$, catalyst weight of $2.5 \mathrm{~g}$, and $\mathrm{O}_{2}$ :dioxane molar ratio of 8 .

ported on zeolite $13 \mathrm{X}$ is sufficiently stable even after continuous usage for $50 \mathrm{~h}$.

Compared with other catalysts used for the oxidation of dioxane $[32,47,49]$, complete oxidation of dioxane over the $\mathrm{Fe} / 13 \mathrm{X}$ catalyst is more efficient in terms of activity, stability of the catalyst, and selectivity for the formation of the complete oxidation products.

\subsubsection{Probable mechanism}

To ascertain the reaction products and track the degradation pathways of dioxane, GC-MS analyses were performed for both the condensable and noncondensable phases of the product mixture. The products identified by GC-MS analyses in both the condensable and noncondensable phase are carbon oxides, EGMF, EGDF, 1,4-dioxane-2-ol, 1,4-dioxane-2-one, and 2-methoxy-1,3-dioxalane. Formation of formic acid, acetic acid, formaldehyde, acetaldehyde, glycolic acid, and methoxyacetic acid has also been reported in photocatalytic degradation of dioxane in industrial wastewater $[43,44]$. However, these compounds are not stable under certain reaction conditions, and these intermediates were not detected in the present study because of the high oxygen concentration and high oxidizing power of the Fe catalyst.

A plausible reaction mechanism for the degradation of dioxane over the Fe/13X catalyst based on the products identified by GC-MS analyses is shown in Scheme 1. Molecular oxygen may be involved in auto-oxidation processes in which the radical intermediates formed in volatile organic compound oxidation are oxidized by $\mathrm{O}_{2}$ [45]. However, chain propagation may not occur when the concentrations of organic compounds are low. Initial adsorption of dioxane on the Fe/13X catalyst occurs, where interaction with the hydroxyl groups on the surface of the catalyst results in formation of the 1,4-dioxane- $\alpha$-oxyl radical. Several studies of dioxane degradation in aqueous media have shown the formation of this radical on the surface of the catalyst material $[46,47]$. The 1,4-dioxane- $\alpha$-oxyl radical reacts with surface hydroxyl groups through path 1 to form 1,4-dioxane-2-ol, which is oxidized by $\mathrm{O}_{2}$ to give 1,4-dioxane-2-one.

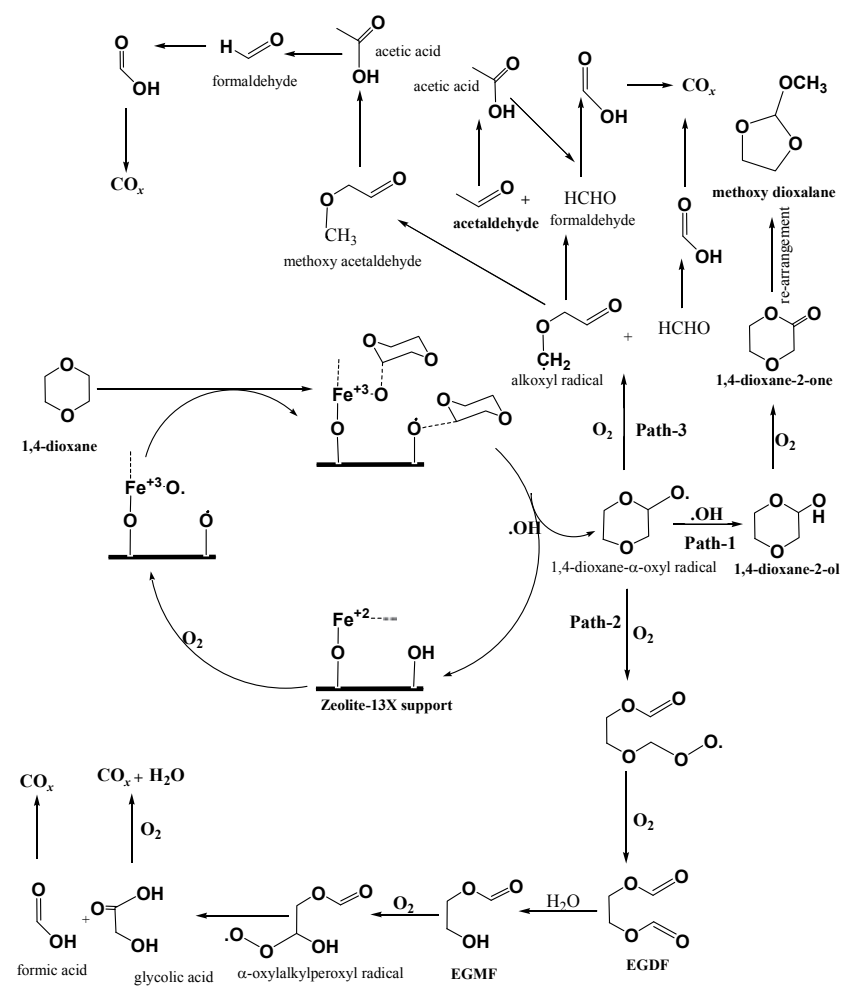

Scheme 1. Plausible degradation pathway for dioxane on the Fe/13X catalyst.

Intramolecular rearrangement of 1,4-dioxane-2-one gives 2-methoxy-1,3-dioxalane. Quantitative analysis of these products by GC-MS reveals that only trace amounts of the products are formed by this route. Hence, it is not an effective pathway for oxidation of dioxane.

Oxidative degradation of the 1,4-dioxane- $\alpha$-oxyl radical through $\Delta \mathrm{C}-\mathrm{C}$ scission at the $\alpha-\mathrm{C}$ position by path 2 leads to the formation of EGDF. Hydrolysis of EGDF gives EGMF, which yields glycolic acid and formic acid by extended oxidative degradation. Several previous studies support the hydrolysis of EGDF and EGMF in the photocatalytic process [47-49].

Path 3 proceeds through abstraction of the $\mathrm{H}$ atom from the $\alpha^{1-C}$ position followed by $\mathrm{C}-\mathrm{C}$ scission to give formaldehyde and the alkoxyl radical. Formaldehyde is readily oxidized to formic acid and then to carbon oxides. The alkoxyl radical either produces methoxyacetaldehyde by reduction or acetaldehyde by $\beta$-cleavage $[46,47,50]$. It is important to note that Path 2 is the predominant path for degradation of dioxane to carbon oxides through EGDF and EGMF. A recent Fourier transform infrared spectroscopy study of oxidation of dioxane with ozone under acidic conditions also supports this argument $[46,49]$. The small acids formed in Paths 2 and 3 are finally oxidized to carbon oxides, which achieves the complete oxidation of dioxane in a continuous flow reactor.

\section{Conclusions}

Among all of the Fe/13X catalysts, the 6 wt\% Fe/13X catalyst exhibited the best catalytic performance of $97 \%$ dioxane 
conversion and $95 \%$ selectivity for $\mathrm{CO}$ and $\mathrm{CO}_{2}$ formation at $400{ }^{\circ} \mathrm{C}$ with a GHSV of $24000 \mathrm{~h}^{-1}$ and an $\mathrm{O}_{2}$ :dioxane molar ratio of 8 . This catalyst also exhibited the highest stability over the temperature range $200-400{ }^{\circ} \mathrm{C}$ even after continuous use for more than $50 \mathrm{~h}$. The TPR, $\mathrm{NH}_{3}$-TPD, surface area, and SEM results reveal that upon increasing the Fe loading, the redox active site density increases with increasing Fe loading up to 6 $\mathrm{wt} \%$, which favors the complete oxidation of dioxane to carbon oxides. Above $6 \mathrm{wt} \% \mathrm{Fe}$, aggregation of iron oxide species occurs on the surface of the zeolite-13X support, thereby decreasing the activity of the catalyst. The process parameters, such as reaction temperature, metal loading, and GHSV, were optimized for complete oxidation of dioxane. This study demonstrates that $6 \mathrm{wt} \% \mathrm{Fe} / 13 \mathrm{X}$ is a promising catalyst for complete degradation of dioxane to carbon oxides.

\section{Acknowledgments}

The authors are grateful to Director DRDE for his keen interest and encouragement to carry out this study.

\section{References}

[1] National Priorities List sites identified by the EPA, 821, 1518.

[2] K. R. Smith, Proceedings of the National Academy of Sciences of the United States of America, 2000, 97, 13286-13293.

[3] S. Budavari, M. J. Neil, A. Smith, P. E. Heckelman, J. F. Kinneary, The Merck Index, 12th ed., Merck \& Co., Inc. Whitehouse Station, NJ, 1996.

[4] National Industrial Chemicals Notification and Assessment Scheme (NICNAS), 1,4-Dioxane Priority Existing Chemical No-7, Full Public Report, Common Wealth of Australia, 1998.

[5] T. Sandy, C. P. Grady Jr., S. Meininger, R. Boe, Annual Industrial Wastes Technical and Regulatory Conference, Conference Proceeding 7th, Charleston, SC, USA, 2001, 88-117.

[6] R. Alnaizy, A. Akgerman, Adv. Environ. Res., 2000, 4, 233-244.

[7] M. J. Zenker, R. C. Borden, M. A. Barlaz, Environ. Eng. Sci., 2003, 20, 423-432.

[8] U.S. Department of Health and Human Services, Seventh Annual Report on Carcinogens, 1994, PB95-109781, 186.

[9] S. Mahendra, C. J. Petzold, E. E. Baidoo, J. D. Keasling, L. Alvarez-Cohen, Environ. Sci. Technol., 2007, 41, 7330-7336.

[10] S. L. Kelley, E. W. Aitchison, M. Deshpande, J. L. Schnoor, P. J. J. Alvarez, Water Res., 2001, 35, 3791-3800.
[11] S. Hand, B. X. Wang, K. H. Chu, Sci. Total Environ., 2015, 520, 154-159.

[12] C. D. Adams, P. A. Scanlan, N. D. Secrist, Environ. Sci. Technol,, 1994, 28, 1812-1818.

[13] S. C. Kwon, J. Y. Kim, S. M. Yoon, W. Bae, K. S. Kang, Y. W. Rhee, J. Ind. Eng. Chem., 2012, 18, 1951-1955.

[14] M. A. Beckett, I. Hua, Water Res., 2003, 37, 2372-2376.

[15] V. Maurino, P. Calza, C. Minero, E. Pelizzetti, M. Vincenti, Chemosphere, 1997, 35, 2675-2688.

[16] R. R. Hill, G. E. Jeffs, D. R. Roberts, J. Photochem. Photobiol. A, 1997, 108, 55-58.

[17] H. M. Coleman, V. Vimonses, G. Leslie, R. Amal, J. Hazard. Mater., 2007, 146, 496-501.

[18] B. K. Min, J. E. Heo, N. K. Youn, O. S. Joo, H. Lee, J. H. Kim, H. S. Kim, Catal. Commun., 2009, 10, 712-715.

[19] K. C. Lee, H. J. Beak, K. H. Choo, Water Res., 2015, 86, 58-65.

[20] H. C. Wang, H. S. Liang, M. B. Chang, J. Hazard. Mater., 2011, 186, 1781-1787.

[21] C. B. Almquist, E. Sahle-Demessie, S. C. Shekar, J. Sowash, Environ. Sci. Technol., 2007, 41, 4754-4760.

[22] H. Finaga, S. Futamura, J. Catal., 2004, 227, 304-312.

[23] M. Iwasaki, M. Hara, S. Ito, J. Mater. Sci. Lett., 1998, 17, 1769-1771.

[24] P. V. Kumar, D. Meisel, Curr. Opin. Colloid. Inerface Sci., 2006, 7, 13920-13925.

[25] D. M. Huang, D. B. Cao, Y. W. Li, H. J. Jiao, J. Phys. Chem. B, 2006, 110, 13920-13925.

[26] O. Shekhah, W. Ranke, A. Schule, G. Kolios, R. Schlogl, Angew. Chem. Int. Ed., 2003, 42, 5760-5763.

[27] A. N. Pour, S. Taghipoor, M. Shekarriz, S. M. K. Shahri, Y. Zamani, J. Nanosci. Nanotechnol., 2009, 9, 4425-4429.

[28] A. N. Pour, M. R. Housaindokht, S. F. Tayyari, J. Zarkesh, J. Nat. Gas. Chem., 2010, 19, 284-292.

[29] S. Eriksson, U. Nylen, S. Rojas, M. Boutonnet, Appl. Catal. A, 2004, 265, 207-219.

[30] L. F. Chen, K. K. Zhu, L. H. Bi, A. Suchopar, M. Reicke, G. Mathys, H. Jaensch, U. Kortz, R. M. Richards, Inorg. Chem., 2007, 46, 8457-8459.

[31] D. Habibi, A. R. Faraji, M. Arshadi, J. L. G. Fierro, J. Mol. Catal. A, 2013, 372, 90-99.

[32] F. Battin, G. Scacchi, F. Baronnet, Int. J. Chem. Kinet., 1991, 23, 861-879.

[33] M. M. J. Treacy, J. B. Higgins, Collection of Simulated XRD Powder Patterns for Zeolites, 4th ed., 2001, 152-153.

[34] S. Lowell, J. E. Shields, M. A. Thomas, M. Thommes, Characterization of Porous Solids and Powders: Surface Area, Pore Size and Density, Springer, 2004, ISBN 1402023022.

\section{Graphical Abstract}

Chin. J. Catal., 2016, 37: 240-249 doi: 10.1016/S1872-2067(15)61030-0

Complete oxidation of 1,4-dioxane over zeolite-13X-supported Fe catalysts in the presence of air

C. Ramakrishna*, R. Krishna, T. Gopi, G. Swetha, Bijendra Saini, S. Chandra Shekar, Anchal Srivastava

Defence Research \& Development Establishment, India

This study investigates zeolite-13X-supported Fe catalysts for the continuous removal of gas-phase 1,4-dioxane, a hazardous and priority pollutant, by catalytic oxidation with air as the oxidant at atmospheric pressure at $200-400{ }^{\circ} \mathrm{C}$.

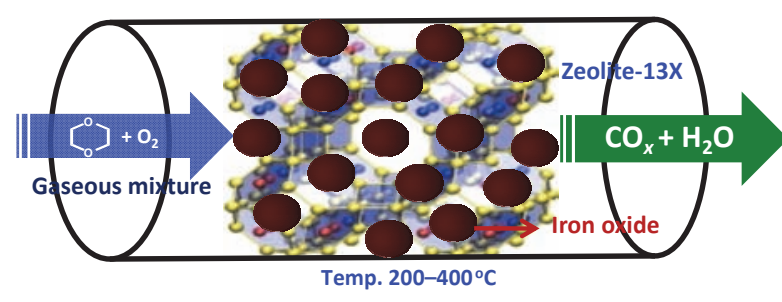


[35] J. Okal, M. Zawadzki, L. Kepinski, L. Krajczyki, W. Tylus, Appl. Catal. A, 2007, 319, 202-209.

[36] W. Q. Yu, B. S. Wu, J. Xu, Z. C. Tao, H. W. Xiang, Y. W. Li, Catal. Lett., 2008, 125, 116-122.

[37] J. H. Ma, B. B. Fan, R. F. Li, J. H. Cao, Catal. Lett., 1994, 23 , 189-194.

[38] G. Munteanu, L. Ilieva, D. Andreeva, Thermochim. Acta, 1997, 291, 171-177.

[39] K. C. Wu, Y. L. Tung, Y. L. Chen, Y. W. Chen, Appl. Catal. B, 2004, 53, 111-116.

[40] G. W. Chen, S. L. Li, F. J. Jiao, Q. Yuan, Catal. Today, 2007, 125, 111-119.

[41] S. C. Shekar, K. Soni, R. Bunkar, M. Sharma, B. Singh, A. Nigam, T. Mahato, R. Vijayaraghavan, Catal. Commun., 2009, 11, 77-81.

[42] V. G. Devulapelli, E. Sahle-Demessie, Appl. Catal. A, 2008, 348, 86-93.
[43] H. Barndõk, D. Hermosilla, C. Han, D. D. Dionysiou, C. Negroa, A. Blanco, Appl. Catal. B, 2016, 180, 44-52.

[44] N. Merayo, D. Hermosilla, L. Cortijo, A. Blanco, J. Hazard. Mater., 2014, 268, 102-109.

[45] K. C. Soni, S. C. Shekar, B. Singh, T. Gopi, J. Colloid Interface Sci., 2015, 446, 226-236.

[46] M. I. Stefan, J. R. Bolton, Environ. Sci. Technol., 1998, 32, 1588-1595.

[47] H. J. Wang, B. Bakheet, S. Yuan, X. Li, G. Yu, S. Murayama, Y. J. Wang, J. Hazard. Mater., 2015, 294, 90-98.

[48] V. Maurino, P. Calza, C. Minero, E. Pelizzetti, M. Vincenti, Chemosphere, 1997, 35, 2675-2688.

[49] H. Barndõk, L. Cortijo, D. Hermosilla, C. Negro, A. Blanco, J. Hazard. Mater., 2014, 280, 340-347.

[50] H. S. Kim, B. H. Kwon , S. J. Yoa, I. K. Kim, J. Chem. Eng. Jpn., 2008, 41, 829-835.

\section{$13 X$ 分子篮负载 $\mathrm{Fe}$ 催化剂上 $1,4-$ 二氧六环在空气中完全氧化 \\ C. Ramakrishna ${ }^{*}$, R. Krishna, T. Gopi, G. Swetha, Bijendra Saini, S. Chandra Shekar, Anchal Srivastava \\ 国防研发局，防化装备评估设备(CDEF)，那格浦尔，MH-441108，印度}

摘要: 采用浸渍法制备了不同 $\mathrm{Fe}$ 含量的13X分子笁负载的 $\mathrm{Fe}$ 催化剂 $(\mathrm{Fe} / \mathrm{X} 13)$, 运用 $\mathrm{N}_{2}$ 吸附-脱附法测得其BET比表面积和 BJH孔径分布, 采用 X射线衍射、扫描电镜、程序升温还原和 $\mathrm{NH}_{3}$ 程序升温脱附法表征了该催化剂的织构性质. 在固定床流 动反应器中, 以空气为氧化剂、在 $100-400{ }^{\circ} \mathrm{C}$ 范围内考察了 $\mathrm{Fe} / \mathrm{X} 13$ 催化剂上 1,4 -二氧六环的完全氧化反应性能, 研究了反应 温度、金属担载量和气体空速(GHSV)等条件对催化氧化降解二氧六环反应性能的影响, 并在 $400{ }^{\circ} \mathrm{C}$ 测定了该催化剂反应 50 $\mathrm{h}$ 的稳定性. 结果表明, $6 \mathrm{wt} \% \mathrm{Fe} / 13$ X催化剂表现出最高的催化性能, 在 $400{ }^{\circ} \mathrm{C}, \mathrm{GHSV}=24000 \mathrm{~h}^{-1}$ 的条件下, 二氧六环转化 率为 $97 \%$, 生成 $\mathrm{CO}$ 和 $\mathrm{CO}_{2}$ 的选择性达 $95 \%$, 降解产物还包括少量的乙醛、乙二醇-甲酸酯、乙二醇二甲酸、1,4-二氧六环-2 醇、1,4-二氧六环-2酮及2-甲氧基1,3二氧戊环. 基于这些经色谱-质谱联用仪检测出的产物, 提出了可能的 1,4-二氧六环降解 机理.

关键词: 铁; 13X分子笁; 1,4-二氧六环; 催化降解; 完全氧化; 降解机理

收稿日期: 2015-09-30. 接受日期: 2015-12-09. 出版日期: 2016-02-05.

*通讯联系人. 电话: +91-7103-280702/+91-8551894451; 传真:+91-7103-280610; 电子信箱: ramakrishna.drde@gmail.com 基金来源：印度国防研发局.

本文的英文电子版由Elsevier出版社在ScienceDirect上出版(http://www.sciencedirect.com/science/journal/18722067). 